\title{
COMPARATIVE ANALYSIS OF THE PROPERTIES OF CONCRETE PRODUCED WITH PORTLAND LIMESTONE CEMENT (PLC) GRADE 32.5N AND 42.5R FOR USE IN RIGID PAVEMENT WORK
}

M. JOEL AND I. D. MBAPUUN

(Received 4 April 2016; Revision Accepted 10 June 2016)

\begin{abstract}
The properties of different grades of concrete produced with Portland limestone Cement (PLC) grades $32.5 \mathrm{~N}$ and $42.5 \mathrm{R}$ was compared in the study. Initial and Final setting time tests were perform on cement paste. Slump and compacting factor test were performed on fresh concrete. Mix ratios of 1:2:4 and 1:3:6 (Cement: Sand: Granite) by volume and mix proportions for Grades 30 and 40 concrete used in different aspect of rigid pavements, were used to cast concrete cubes and beams that were subjected to compression and flexural strength test after curing for 7, 14, 28 and 56 days respectively. Compressive and flexural strength values of concrete produced with PLC grade 42.5R were higher than values obtained with grade 32.5 . The 28 day compressive strength values of concrete produced with PLC grade 42.5R were, 28.0, 30.0, 35.0, and $40.0 \mathrm{~N} / \mathrm{mm},{ }^{2}$ while values of 22.0, 28.0, 33.0 and 35.0 were obtained with PLC grade 32.5, for mix ratios of 1:3:6, 1:2:4 and Grade 30 and 40 concrete respectively. Similar trend was observed with flexural strength values. Based on result of test PLC grade $42.5 \mathrm{R}$ is an improvement over grade 32.5 and its usage in rigid pavement construction work is recommended as it ensures higher strength and economy in concrete work.
\end{abstract}

KEYWORDS: Cement, Concrete, compressive strength, Flexural strength.

\section{INTRODUCTION}

Roads are very vital for the economic well being of any nation, and are critical in the transportation of goods and services in Nigeria. Two types of pavement are commonly in use in Nigeria, the flexible and rigid pavement. Flexible pavements are multilayer system while rigid pavement is made up of concrete. In the face of failure associated with flexible pavement in different parts of Nigeria. Rigid pavement is most likely a viable alternative, since its lifespan is longer than that of flexible pavement, although its initial cost is greater than flexible pavement. Its maintenance cost and overall cost taking life span and load carrying capacity into consideration is better than the flexible pavement.

Concrete used in rigid pavement construction is normally produced with the use of aggregate, cement and water. Aggregate used in concrete work is divided into fine and coarse aggregate, while cement serves as the binder, in the presence of water that initiate hydration reaction. Cements may be defined as adhesive substances capable of uniting fragments or masses of solid matter to a compact whole (Ghosh, 1983). Cement is normally employed in the production of concrete used in different aspects of rigid pavement work, such as the main carriage way, streets, pedestrian walkway, kerbstones, medians, road dividers, parking lots, highway side drain, culverts and bridges.

Cement is the most expensive component in a cubic metre of concrete and its properties affects the properties of concrete the most. Strength of concrete is normally determined using compressive strength value, although flexural strength is the indices used in rigid pavement work. The compressive strength

M. Joel, Civil Engineering Department, University of Agriculture, P.M.B, 2373 Makurdi, Benue State, Nigeria.

I. D. Mbapuun, Civil Engineering Department, University of Agriculture, P.M.B, 2373 Makurdi, Benue State, Nigeria. 
of concrete according to Adewoke, et al (2014) largely depends on the quality and quantity of cement that serves as the major strength giver in concrete, as it binds the fine and coarse aggregate together to form a rigid/solid mass that is capable of sustaining load.

There are three grades of cement namely 33, 43 and 53 respectively. The grades corresponds to the minimum $28^{\text {th }}$ day compressive strength of cement, also referred to as cement strength classes of $32.5 \mathrm{Mpa}, 42.5$ Mpa and 52.5 Mpa respectively. In terms of strength, the classes of cement are $32.5 \mathrm{~N}$, $32.5 \mathrm{R}, 42.5 \mathrm{~N}, 42.5 \mathrm{R}, 52.5 \mathrm{~N}, 52.5 \mathrm{R}$. The 32.5 category must have strength between $32.5 \mathrm{~N} / \mathrm{mm}^{2}$ and $52.5 \mathrm{~N} / \mathrm{mm}^{2}$, while the 42.5 grade, has a strength range between $42.5 \mathrm{~N} / \mathrm{mm}^{2}$ and 52 . $5 \mathrm{~N} / \mathrm{mm}^{2}$. The minimum strength of the third category is $52.5 \mathrm{~N} / \mathrm{mm}^{2}$. These are strengths after 28days. While the appendage "N" refers to a class of cement with ordinary early strength, " $R$ " Refers to those with high early strength. (Oyenuga, 2014).

A summary of the history of cement in Nigeria shows that before the adoption and implementation of the present Nigerian Industrial Standards for cement NIS 444-1(2003) which had provisions for different grades and types of cement. Ordinary Portland cement was the only cement known and available in Nigerian market, and the only cement approved for production by NIS 11 (1974). Both NIS 11 (1974) and NIS 439 (2000) did not make any provision for the production of cement of different grades. NIS 439 (2000) specified that OPC be made of clinker and gypsum both of which constitute 95 to $100 \%$ of the cement and 0 to $5 \%$ minor additional constituent of calcarious materials (example limestone).

OPC which is now simply referred to as Portland cement and designated as CEM 1 in the present Nigerian Industrial Standards for cement NIS 444-1 (2003) is exactly the same OPC/CEM I specified in NIS 439 (2000) Adewoke, et al (2014) established and reported that OPC/CEM 1 is not available in the open market in Nigeria, it can only be obtain in bulk form on request from the cement factories. This observation was collaborated through market survey that confirms that OPC/CEM 1 is not available in Nigerian open market. The cement available in the open market in Nigeria is the Portland-limestone cement designated as CEM II in NIS 444-1 (2003). According to Palmer, Jnr (2014), PLC is a slightly modified version of Portland cement that improves both the environmental footprint and potentially the basic performance of concrete. While ordinary Portland cement (OPC) may contain up to $5 \%$ limestone, PLC contains between $5 \%$ and $15 \%$ limestone.

Portland-limestone cement/CEM II is produced by adding 6-35\% of limestone to OPC. It has a lower clinker content range of $65-94 \%$ compared with OPC's range of $95-100 \%$. Clinker is the main strength given constituent of cement. Limestone is used in Portland limestone cement/CEM II because it is easier to grind than clinker and is cheaper than clinker. (Hawkins et al, 2003). Portland-limestone cement/CEM II with $80 \%-94 \%$ clinker and $6-20 \%$ limestone is designated as CEM II/A-L while Portlandlimestone cement/CEM II with 65-79 \% clinker and $21-35 \%$ limestone is designated as CEM II/B-L.

In 2014, the Standards Organisation of Nigeria (SON) restricted the use of PLC grade $32.5 \mathrm{~N}$ to only plastering work. The restriction was due to frequent collapse of buildings arising from the misuse of PLC grade $32.5 \mathrm{~N}$, and ignorance regarding the difference between PLC grade $32.5 \mathrm{~N}$ and 42.5 . In response to the directive of SON in the year 2014 , one of the major cement producing companies in Nigeria launched the PLC grade $42.5 \mathrm{R}$ to replace its grade $32.5 \mathrm{~N}$. The new grade of cement according to the company had extra strength, extra life and extra yield and rapid hardening and sold at the same price as grade $32.5 \mathrm{~N}$.

The properties of concrete produced with different grades and types of cement have been reported by researchers. Mathur et al (2014) conducted a comparative analysis of the properties of concrete produced with OPC and fly ash- based Portland pozzolana cement grade 42.5 and grade 52.5 in India, and reported differences in properties. Hodhod and Abdeen (2010) conducted a comparative study on the properties of concrete produced with OPC grades 52.5, 42.5 and 32.5; Portland-Slag cement of grade 32.5(CEM II-B-S $32.5 \mathrm{~N}$ ) and Portlandlimestone cement of grade 32.5 (CEM II-B-L$32.5)$ in Egypt and reported differences in properties studied. In Nigeria the effects of PLC grades $32.5 \mathrm{~N}$ and $42.5 \mathrm{~N}$ generally used for concrete production was investigated by Kazeem, et al (2014). Different mix ratios associated with building construction were used in the study. Comparison of the 28 day compressive strength values of concrete produced with two grades of cement showed that 
higher strength were obtained with PLC grade $42.5 \mathrm{~N}$ when compared with concrete produced with PLC grade $32.5 \mathrm{~N}$.

Based on the review of literature, little or nothing has been documented on the comparison of the properties of concrete produced with Portland-limestone cement grade $32.5 \mathrm{~N}$ and grade $42.5 \mathrm{R}$, used in the construction of different components of rigid pavement. The importance of the comparison can hardly be overemphasized; such study is expected to reveal the difference in the properties of concrete produced with the two grades of concrete used in rigid pavement work. This study is aimed at investigating the plastic and hardened properties of different grades of concrete used in rigid pavement work, produced with PLC grade 32.5 $\mathrm{N}$ and $42.5 \mathrm{R}$. The hardened properties are assessed using compressive and flexural strength of concrete at different ages.

\section{MATERIALS AND METHODS}

PLC grade $32.5 \mathrm{~N}$ and grade $42.5 \mathrm{R}$ used in the study were obtained from the open market in Makurdi, The two grades of PLC were manufactured by a cement company located in Benue State, Nigeria. The fine aggregate used was river sand obtained from river Benue in Makurdi. Coarse aggregates used was crushed granite of aggregate size $20 \mathrm{~mm}$, as found in the building materials market in the Wurukum area of
Makurdi. Water was obtained from the Civil Engineering Laboratory at the University of Agriculture Makurdi, concrete Laboratory.

\section{METHODS}

Laboratory tests performed on fine and coarse aggregates include particle size distribution, specific gravity, while aggregate Impact and crushing value tests were performed on the coarse aggregate in accordance with BS 812 (1990) part 110 and 112. In order to determine the chemical constituents of PLC grades $32.5 \mathrm{~N}$ and $42.5 \mathrm{R}$. samples were taken and subjected to analysis in the laboratory of National Steel Council, Kaduna, using X-ray analyzer together with Atomic Absorption Spectrophotometer (AAS). Setting time and soundness of cement was conducted in accordance with BS EN 196-3 (2005).

Concrete was produced with a mix proportion of 1:3:6 and 1:2:4 (Cement: Sand: Granite) by volume, while Mixed design was carried out for concrete grade 30 and 40 using the procedure for the design of normal concrete mixes (DOE, 1988). The different grades of concrete and mix proportion adopted in this study covered the different grades of concrete used in the different aspects of rigid pavement work. The constituent materials for grade $\mathrm{C} 30$ and $\mathrm{C} 40$ concrete batched by weight, is presented in Table 1.

Table 1: Summary of mix design for grade $\mathrm{C} 30$ and $\mathrm{C} 40$ concrete in $\mathrm{Kg} / \mathrm{m}^{3}$ of concrete

\begin{tabular}{|l|l|l|}
\hline Grade of concrete & C30 & C40 \\
\hline Materials & \multicolumn{2}{|c|}{ Quantity $\left(\mathrm{kg} / \mathrm{m}^{3}\right)$} \\
\hline Cement & 313 & 360 \\
\hline Sand & 730 & 762 \\
\hline Crushed Granite & 1244 & 1243 \\
\hline Water & 172 & 180 \\
\hline
\end{tabular}

Setting times test (Initial and final) were carried out in accordance with BSEN 1963(2005), on the two grades of PLC using the Vicat probe and the Vicat needle apparatus. Slump test was carried out in accordance with the provisions of BSEN 12350-2 (2000). The slump test was performed before concrete for cube and rectangular specimen were placed in their respective moulds.

\section{Compression strength tests}

Compressive strength test were conducted on $150 \mathrm{~mm} \times 150 \mathrm{~mm} \times 150 \mathrm{~mm}$ cube specimens, in accordance with BS EN 12390-2 (2000). A total of 96 concrete cubes were cast, 24 for grade 30 and 24 for grade 40 concrete respectively. Materials were mixed at ambient temperature using a rotating pan type mixer. The quantity of concrete prepared for each batch was 
at least $10 \%$ in excess of the required amount. Mixing of the constituent materials was undertaken for six and a half minutes. Immediately after completion of the mixing process, the fresh concrete was sampled for slump test. After the slump test, the fresh concrete was placed in a concrete cube moulds in two layers. Each concrete layer was compacted by Roding in the manner specified by BSEN 12390-2 (2000), after which the moulds with their contents were vibrated on an ELE vibrating Table for 5 minutes, before storage for 24 hours to allow the concrete to set before demoulding and curing. The concrete cube specimens were cured by complete immersion in water in a curing tank. The compressive strength of the concrete cube was determined at ages of 7, 1428 and 56 days respectively, in accordance with BS EN 12390-3(2009)

\section{Flexural Strength Test}

Flexural strength was carried out on two concrete beams or rectangular specimens of sizes $500 \mathrm{~mm} \times 100 \mathrm{~mm} \times 100 \mathrm{~mm}$, in accordance with the provision of BS EN 123905(2009). In preparing specimens for flexural strength test, fresh concrete was placed in the rectangular moulds in two layers, each concrete layer was compacted by roding in the manner specified by BS EN 12390-2 (2000), after which the mould and its content was vibrated on an ELE vibrating table for 5 minutes, before storage for 24 hours to allow the concrete to set before demoulding and curing. The beam specimens were cured for 7,14 and 28 days by complete immersion in a curing tank before it was subjected to test using a mini flexural testing machine. The third point loading method was used in loading the sample to failure.

Flexural strength was calculated using equation 2 given as

$f b t=\frac{p l}{b d^{3}}$

Where $f_{b t}=$ Flexural strength $\mathrm{N} / \mathrm{mm}^{2}, P=$ Maximum load in $(\mathrm{kN})$ applied to the specimen before failure.

$L=$ span of beam, $b=$ width of the beam $(\mathrm{mm}), d$ $=$ depth of beam $(\mathrm{mm})$

\section{RESULTS AND DISCUSSION}

Oxide composition analysis of PLC grade $32.5 \mathrm{~N}$ and 42. $5 \mathrm{R}$ is presented as Table 2 .

Table 2: Chemical Composition of CCR and Cement.

\begin{tabular}{|c|c|c|c|c|c|c|c|c|c|c|c|c|c|}
\hline $\begin{array}{l}\text { Oxide } \\
\text { Compositio } \\
\text { n }\end{array}$ & $\mathrm{SiO}_{2}$ & $\begin{array}{l}\mathrm{TiO} \\
2\end{array}$ & $\begin{array}{l}\mathrm{Al}_{2} \mathrm{O} \\
3\end{array}$ & $\begin{array}{l}\mathrm{Fe}_{2} \mathrm{O} \\
3\end{array}$ & $\mathrm{SO}_{3}$ & $\mathrm{CaO}$ & $\begin{array}{l}\mathrm{Mg} \\
\mathrm{O}\end{array}$ & $\begin{array}{l}\mathrm{Na}_{2} \\
\mathrm{O}\end{array}$ & $\mathrm{K}_{2} \mathrm{O}$ & $\begin{array}{l}\mathrm{Mn} \\
\mathrm{O}\end{array}$ & $\begin{array}{l}\mathrm{V}_{2} \mathrm{O} \\
5\end{array}$ & $\begin{array}{l}\mathrm{Ba} \\
\mathrm{O}\end{array}$ & LOI \\
\hline $\begin{array}{l}\text { Grade } \\
32.5 \mathrm{~N}\end{array}$ & $\begin{array}{l}20.4 \\
0\end{array}$ & $\begin{array}{l}0.3 \\
8\end{array}$ & 5.60 & 2.50 & $\begin{array}{l}2.5 \\
4\end{array}$ & $\begin{array}{l}64.0 \\
0\end{array}$ & 1.69 & 0.59 & $\begin{array}{l}0.5 \\
7\end{array}$ & 0.15 & 0.04 & $\begin{array}{l}0.0 \\
6\end{array}$ & $\begin{array}{l}1.2 \\
0\end{array}$ \\
\hline $\begin{array}{l}\text { Grade } \\
42.5 \mathrm{R}\end{array}$ & $\begin{array}{l}17.1 \\
6\end{array}$ & $\begin{array}{l}0.3 \\
7\end{array}$ & 5.53 & 2.60 & $\begin{array}{l}2.4 \\
8\end{array}$ & $\begin{array}{l}68.4 \\
7 \\
\end{array}$ & 1.43 & 0.54 & $\begin{array}{l}0.3 \\
2\end{array}$ & 0.14 & 0.02 & $\begin{array}{l}0.0 \\
5\end{array}$ & $\begin{array}{l}1.0 \\
0\end{array}$ \\
\hline
\end{tabular}

LOI= Loss on Ignition.

The chemical composition of PLC grade $32.5 \mathrm{~N}$ and 42. $5 \mathrm{R}$ have adequate compounds required for effective hydration of cement. Results of some tests conducted on the two grades of cements used in the study is presented in Table 3

Table 3: Some Properties of PLC grade $32.5 \mathrm{~N}$ and $42.5 \mathrm{R}$.

\begin{tabular}{|l|l|l|}
\hline Property & PLC grade $32.5 \mathrm{~N}$ & PLC grade 42.5 R \\
\hline Specific Gravity & 3.15 & 3.15 \\
\hline Consistency & $20 \mathrm{mins}$ & $16 \mathrm{mins}$ \\
\hline Initial setting time & $201 \mathrm{mins}$ & $117 \mathrm{mins}$ \\
\hline Final setting time & $429 \mathrm{mins}$ & $258 \mathrm{mins}$ \\
\hline Soundness & $7 \mathrm{~mm}$ & $5 \mathrm{~mm}$ \\
\hline
\end{tabular}


Setting times test results shows that the initial setting time value of 201 mins for Grade $32.5 \mathrm{R}$ cement is almost twice the value of $117 \mathrm{mins}$ for Grade $42.5 \mathrm{~N}$. Both values are above minimum value of $60 \mathrm{mins}$ for Grade $32.5 \mathrm{~N}$, $32.5 \mathrm{R}, 42.5 \mathrm{~N}$, and $42.5 \mathrm{R}$ grade of cement prescribed by BS EN 196-3.

Final setting time of PLC grade $42.5 \mathrm{~N}$ was $4 \mathrm{hrs}, 18$ minutes while that of PLC grade $32.5 \mathrm{R}$ was $7 \mathrm{hrs}$, 9minutes. Both values are below the maximum value of 10 hours specified by BS EN 196-3 for OPC, hence it is adequate. Soundness test value of $5 \mathrm{~mm}$ and $7 \mathrm{~mm}$ obtained for PLC grade $42.5 \mathrm{~N}$ and $32.5 \mathrm{R}$ respectively are lower than the upper limit value of $10 \mathrm{~mm}$ specified by BS EN 196-3 (2005).

Summary of the different test performed on coarse and fine aggregate is as presented in Table 4. The coarse aggregate used was crushed rock with a maximum size of $20 \mathrm{~mm}$. particle size distribution of fine aggregate used in the study is presented in Figure 1.

Table 4: Result of tests conducted on Coarse and fine Aggregate

\begin{tabular}{|l|l|l|l|l|}
\hline Property & Specific gravity & $\begin{array}{l}\text { Aggregate } \\
\text { crushing value } \\
(\%)\end{array}$ & $\begin{array}{l}\text { Aggregate } \\
\text { impact value } \\
(\%)\end{array}$ & $\begin{array}{l}\text { Fineness } \\
\text { Modulus }\end{array}$ \\
\hline Coarse Aggregate & 3.05 & 24.0 & 19 & 3.41 \\
\hline Fine Aggregate & 2.60 & - & - & 5.16 \\
\hline
\end{tabular}

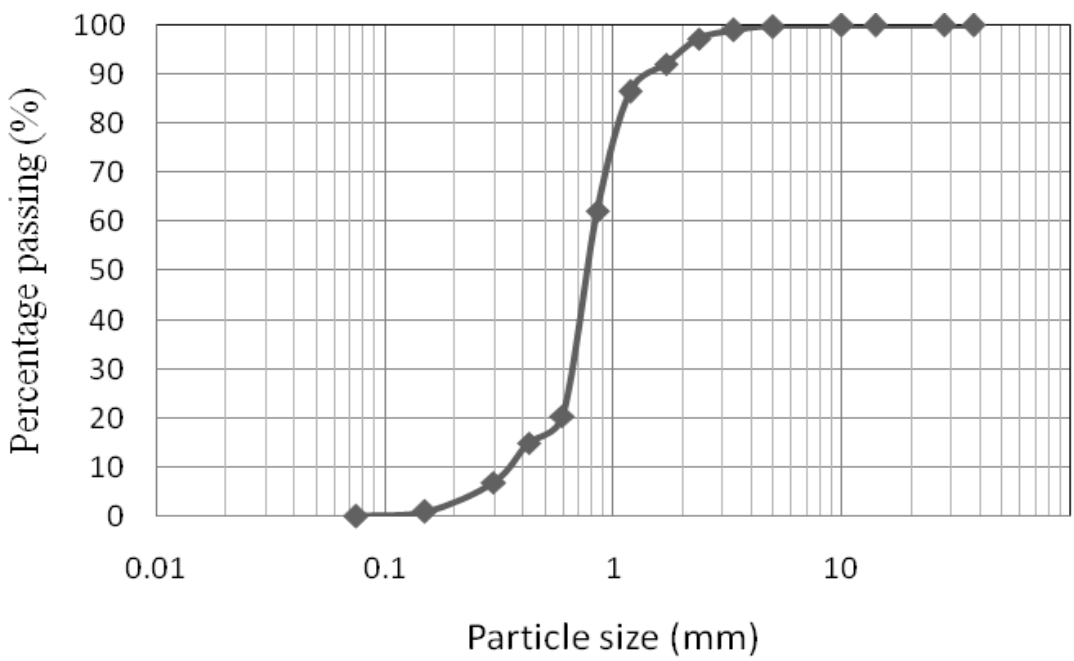

Figure 1: Particle size distribution curve of Makurdi River sand.

\section{Water Cement Ratio}

The water to cement ratio used to prepare concrete with the different mix proportion and grade of concrete with PLC grade $32.5 \mathrm{~N}$ and
$42.5 \mathrm{R}$ and the slump values obtained with the different grades of concrete and mix proportion is presented in Table

5. 
Table 5: Slump test results

\begin{tabular}{|l|l|l|l|}
\hline Grade of Concrete & $\begin{array}{l}\text { Water/cement } \\
\text { Ratio }\end{array}$ & $\begin{array}{l}\text { PLC grade 32.5N } \\
\text { Slump value }(\mathrm{mm})\end{array}$ & $\begin{array}{l}\text { PLC grade 42.5R } \\
\text { Slump value }(\mathrm{mm})\end{array}$ \\
\hline $1: 3: 6$ & 0.63 & $40 \mathrm{~mm}$ & $40 \mathrm{~mm}$ \\
\hline $1: 2: 4$ & 0.55 & $50 \mathrm{~mm}$ & $45 \mathrm{~mm}$ \\
\hline 30 & 0.53 & $50 \mathrm{~mm}$ & $50 \mathrm{~mm}$ \\
\hline 40 & 0.50 & $55 \mathrm{~mm}$ & $55 \mathrm{~mm}$ \\
\hline
\end{tabular}

Workability defined as the ease of handling, compacting, placing and finishing, is normally measured using slump value. The slump values in Table 5 . are within the range of 20 to $80 \mathrm{~mm}$ specified by BS EN 12350-2: (2000).

\section{Compressive Strength Test}

The compressive strength test result of concrete cubes produced with PLC grades 32.5 $\mathrm{N}$ and $42.5 \mathrm{R}$ using different mix proportion and grades of concrete is presented in Figure 2.

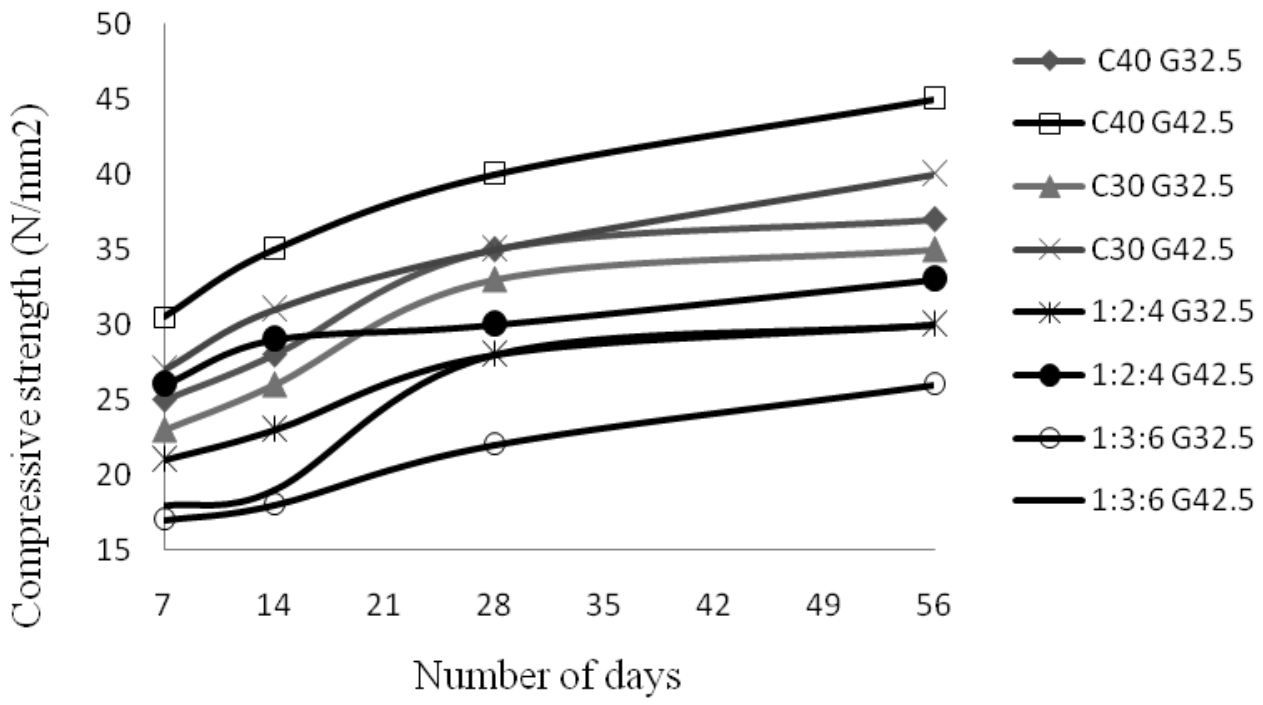

Figure 2 : Variation of compressive strength with days and grade of cement and concrete.

The compressive strength value of concrete cubes at different ages produced with PLC grades $42.5 \mathrm{R}$ using different mix proportion and grades of concrete are higher than values obtained with concrete produced with PLC grade 32. $5 \mathrm{~N}$. Higher strength values associated with PLC grade 42 . 5R can be attributed to its rapid hardening property as it contains more tricalcium silicate, and is more finely grounded than the normal cement. These factors are responsible for higher strength gain experience with PLC grade 42. $5 \mathrm{R}$ when compared with PLC grade $32.5 \mathrm{~N}$. 28 day compressive strength value of 28.0 $\mathrm{N} / \mathrm{mm}^{2}$ for concrete produced with mix ratio of 1:3:6 using PLC grade $42.5 \mathrm{R}$ is greater than the value of $22.0 \mathrm{~N} / \mathrm{mm}^{2}$ by $27 \%$ obtained for the same mix proportion using PLC grade $32.5 \mathrm{~N}$. Concrete mix ratio of $1: 3: 6$ is normally used in blinding work and preparation of surfaces to receive concrete in rigid pavement work. 
28 day compressive strength value of 30 $\mathrm{N} / \mathrm{mm}^{2}$ for concrete produced with mix ratio of 1 : $2: 4$, using PLC grade $42.5 \mathrm{R}$ is greater than the value of $25.0 \mathrm{~N} / \mathrm{mm}^{2}$ by $20 \%$ obtained for the same mix proportion using PLC grade $32.5 \mathrm{~N}$. Concrete mix ratio of $1: 2: 4$ is used in producing concrete used for kerbstone, pedestrian walkway mileage stone and others.

28 day compressive strength value of 35 $\mathrm{N} / \mathrm{mm}^{2}$ for concrete grade C30 produced with PLC grade $42.5 \mathrm{R}$ is greater than the value of 30 $\mathrm{N} / \mathrm{mm}^{2}$ by $17 \%$ obtained for the same grades of concrete using PLC grade $32.5 \mathrm{~N}$. C30 concrete is normally used to produce concrete slab in lightly traffic road, construction of drainage structures, highway medians and other relevant pavement structures.

28 day compressive strength value of $42.0 \mathrm{~N} / \mathrm{mm}^{2}$ for concrete grade C 40 produced with PLC grade $42.5 \mathrm{R}$ is greater than the value of $35 \mathrm{~N} / \mathrm{mm}^{2}$ by $20 \%$ obtained for the same grade of concrete using PLC grade $32.5 \mathrm{~N}$. Grade C40 concrete is normally used to produced concrete slab in moderately traffic road with medium traffic. Results clearly shows that PLC grade $42.5 \mathrm{R}$ exhibit improved strength when compared with PLC grade $32.5 \mathrm{~N}$, in all aspects of rigid pavement work where both grades of cement was used. The same trend observed with 28 day compressive strength values was observed with 56 days compressive strength of different grades of concrete produced with PLC grade $32.5 \mathrm{~N}$ and 42.5 R.

\section{Flexural Strength Test}

The flexural strength test result of concrete produced with PLC grades $32.5 \mathrm{~N}$ and $42.5 \mathrm{R}$ using different mix proportion and grades of concrete is presented in Figure 3 .

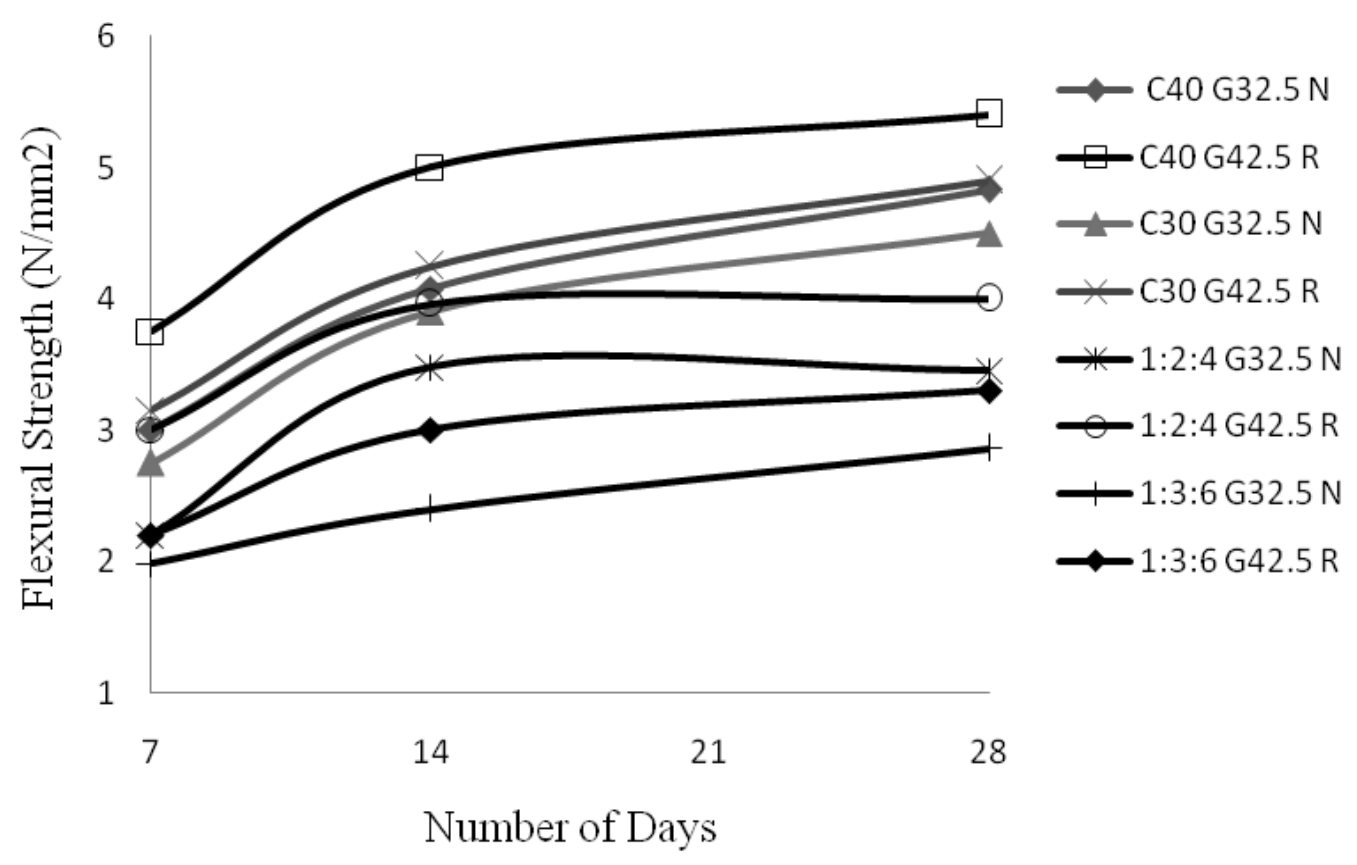

Figure 3: Variation of Flexural strength with days and grade of cement and concrete

The flexural strength value of concrete at different ages produced with PLC grade $42.5 \mathrm{R}$, using different mix proportion and grades of concrete are greater than values obtained with concrete produced with PLC grade $32.5 \mathrm{~N}$. 28 day flexural strength value of $3.03 \mathrm{~N} / \mathrm{mm}^{2}$ for 
concrete produced with mix ratio of 1:3:6 using PLC grade $42.5 \mathrm{R}$ was greater than the value of $2.86 \mathrm{~N} / \mathrm{mm}^{2}$ obtained for the same mix proportion by $15 \%$ using PLC grade $32.5 \mathrm{~N} .28$ day flexural strength value of $4.00 \mathrm{~N} / \mathrm{mm}^{2}$ for concrete produced with mix ratio of 1:2:4 using PLC grade $42.5 \mathrm{R}$ was higher than the value of $3.45 \mathrm{~N} / \mathrm{mm}^{2}$ by $16 \%$ obtained for the same mix proportion using PLC grade $32.5 \mathrm{~N}$.

28 day flexural strength value of 4.90 $\mathrm{N} / \mathrm{mm}^{2}$ for concrete grade C30 produced with PLC grade $42.5 \mathrm{R}$ was higher than the value of $4.20 \mathrm{~N} / \mathrm{mm}^{2}$ by $17 \%$, using PLC grade $32.5 \mathrm{~N}$. The flexural strength values of C30 concrete produced with PLC grade $42.5 \mathrm{R}$ is higher than the minimum value of $4.1 \mathrm{~N} / \mathrm{mm}^{2}$ specified by ACPA (2008) for medium or average traffic roads. Although the value of $4.20 \mathrm{~N} / \mathrm{mm}^{2}$ obtained with PLC grads $32.5 \mathrm{~N}$ is above the minimum value specified, the use of PLC grade $42.5 \mathrm{R}$ is preferred to grade $32.5 \mathrm{~N}$. Based on this assessment concrete grade $\mathrm{C} 30$ produced with PLC grade $42.5 \mathrm{R}$ is recommended for use in the production of slab for medium or average traffic roads.

28 day flexural strength value of 5.40 $\mathrm{N} / \mathrm{mm}^{2}$ for concrete grade $\mathrm{C} 40$ produced with PLC grade $42.5 \mathrm{R}$ was higher than the value of $4.63 \mathrm{~N} / \mathrm{mm}^{2}$ by $17 \%$, obtained for the same grade of concrete using PLC grade $32.5 \mathrm{~N}$. The minimum flexural strength value of $4.5 \mathrm{~N} / \mathrm{mm}^{2}$ specified for concrete slab for highly traffic road (ACPA, 2008) was satisfied by concrete produced with the two grades of cement. The use of PLC grade $42.5 \mathrm{R}$ is preferred to PLC grade $32.5 \mathrm{~N}$, because of the higher strength associated with PLC grade 42.5 R.

\section{CONCLUSION AND RECOMMENDATION}

\section{CONCLUSIONS:}

The following conclusions can be drawn from the study

1. The initial and final setting times of PLC grade $42.5 \mathrm{R}$ is less than that obtained with PLC grade $32.5 \mathrm{~N}$. However all the values obtained are within the acceptable limits.

2. The specific gravity values of PLC grade $42.5 \mathrm{R}$ and $32.5 \mathrm{~N}$ were determined to be 3.15 respectively.

3. $7,14,28$ and 56 days, compressive strength value of concrete produced with PLC grade 42.5R were higher than values obtained with PLC grade $32.5 \mathrm{~N}$.
The result shows that PLC grade 42.5 exhibit improvement in strength over PLC grade $32.5 \mathrm{~N}$.

4. 7,14 and 28 days, flexural strength value of concrete produced using PLC grade 42.5 $\mathrm{R}$ were higher than values obtained with PLC grade $32.5 \mathrm{~N}$ the result shows that PLC grade 42.5R exhibited improved strength over PLC grade $32.5 \mathrm{~N}$

Based on compressive and flexural strength results obtained from the study the use of PLC grade 42.5R to produce concrete for use in rigid pavement construction work is highly recommended as PLC grade 42.5 exhibited improvement in strength over PLC grade $32.5 \mathrm{~N}$.

\section{REFERENCES}

ACPA, 2008. Concrete pavement field reference Pre-paving. American Concrete Pavement Association, Skokie, Illinois, www. pavement .com.

Adewoke, K. K., Olutoge, F. A and Habib, H., 2014. Effect of Nigerian Portland-Limestone cement grades on concrete compressive strength. International Journal of Civil, Environmental, structural construction and Architectural Engineering 8, (11):1140-1143.

BS 812, 1990. Part 110: Methods for Determination of Aggregate Crushing Value. British Standard Institution, London.

BS 812, 1990. Part 112: Methods for Determination of Aggregate Impact Value. British Standard Institution, London.

BS EN 196 part 3. 2005. Methods of testing cement. Determination of setting time and soundness. British Standards Institute London.

BS EN 197 part 1. 2011. Cement Part 1; composition, specifications and conformity criteria for common cements, British Standards Institute.

BS EN 12350 Part 2. 2000. Methods for 
determination of slump. British Standards Institute London.

BS EN 12390 Part 2. 2000.Making and curing specimens for strength tests. British Standards Institute London.

BS EN 12390 Part 3. 2009. Testing hardened concrete: compressive strength of test specimens. British Standards Institute London.

BS EN 12390 Part 5. 2009. Testing hardened concrete: Flexural strength of test specimens. British Standards Institute London.

DOE, 1988. Note on mix design method. Building Research Establishment Laboratory, Department of Environment (DOE). London. UK.

Ghosh, S. N., 1983. Advances in Cement Technology: critical reviews and case studies on manufacturing, quality control, optimization and use. Pergamon Press, Oxford, UK.

Hodhod, A. H and Abdeen, M. A. M., 2010. Experimental comparative and numerical predictive studies on strength evaluation of cement types: effects of specimen shape and type of sand. Scientific research engineering, 2: 559-572.

Kazeem, K. A., Festus, A. O and Hamzat, H., 2014. Effect of Nigerian Portland-Limestone cement grades on concrete compressive strength. International Journal of Civil, Environmental, structural, Construction and Architectural Engineering. (11): 1140-1143.
Mathur, R., Misra, A. K and Goel, P., 2014. Strength of concrete vs Grades of cement, Central Road research Instiute, New

Delhi. http://www.nbmcw.com/articles/concrete/ 25796-strength-of-concrete vs-grades-ofcement $\mathrm{html}$. assessed on $25^{\text {th }}$ April, 2014.

NIS 11., 1974. Specification for ordinary Portland cement, Standard organisation of Nigeria.

NIS 444-1., 2003. Composition, specification and conformity criteria for common cements. Standards Organisation of Nigeria.

NIS 439., 2000. Standard for cement. Standard for cement. Standards Organisation of Nigeria.

Oyenuga, V., 2014. Cement not Responsible for Building Collapse in Nigeria. An Editorial in This day Newspapers of $13^{\text {th }}$ May 2014.

Palmer, Jr. D. W., 2014. Enhancing concrete performance with Portland limestone cement. The Concrete producer JulyAugust.

SON., 2014. Standard Organisation of Nigeria and Portland cement. Vanguard Newspaper of $6^{\text {th }}$ August, 2014. www.vanguardsngr.com/2014/08/standar ds-organisation-nigeria-portlandcement/accessed on 03/02/2016. 